\title{
ENERGY ALTERNATIVES IN LARGE-SCALE WASTEWATER TREATMENT
}

\author{
Zoltán Gabnai ${ }^{1}$ \\ ${ }^{1}$ University of Debrecen, Faculty of Economics and Business, \\ Institute of Applied Economics, Department of Business Economics \\ 4032 Debrecen, 138. Böszörményi St. \\ E-mail: gabnai.zoltan@econ.unideb.hu
}

\begin{abstract}
In my article, after describing the characteristics of recent wastewater treatment activity, I introduce different traditional and innovative energetic opportunities of the compulsory waste management activities at large-scale operational level, covering national and international examples. Furthermore, the wastewater-based biomethane production and the certain plant's energy self-sufficiency are highlighted topics as well. In the former case, it is possible to utilize the wastewater-based biomethane as fuel (and even to operate own vehicle fleet), while the second one gives the opportunity for the internal usage of produced electricity and waste heat, which can also result in significant cost-savings. As an additional option, algae-based wastewater post treatment is presented, based on the conditions of a Hungarian wastewater treatment plant, which biogas production efficiency and thus energy self-sufficiency has developed favourably due to the technological improvements. These plants may have a twofold role in the future: they are responsible for the compulsory waste management activity and on the other hand they can serve as excellent raw material mines.
\end{abstract}

Keywords: wastewater treatment, activated sludge, biogas, algae, biomethane.

(JEL Code: Q25)

\section{INTRODUCTION}

The global population growth, economic development and increase in living standards result in increasing the (1) quantity of waste and by-products, (2) level of environment pollution and (3) energy demand. So, there are strict compulsory environmental regulations and obligations. All of these result in growing demand for similar technologies and solutions:

Efficient, environmentally friendly by-products / waste management.

Efficient, environmentally responsible and material-saving operation, where energy production is also conducted in.

According to the information in Table 1., there are big differences between the continents regarding the number of plants/settlements and the total produced and treated quantity of wastewater. In Europe, more than $70 \%$ of the whole quantity is treated, while in Asia, this proportion is less than 50\% (FAO, 2016). In addition, most of the produced wastewater is treated in large-scale wastewater treatment plants. The main influencing factors are the population of the given country, the living standards, the economic conditions of the country or area, the level of technology and the size of settlements and plants.
Table 1: Characteristics of wastewater treatment on Earth

\begin{tabular}{|c|c|c|c|c|}
\hline Continent & Country & $\begin{array}{c}\text { Number of } \\
\text { plants }\end{array}$ & $\begin{array}{l}\text { Total quantity } \\
\text { (billion } \mathbf{m}^{3} \text { ) }\end{array}$ & $\begin{array}{c}\text { Treated } \\
\text { quantity } \\
\text { (billion } \mathbf{m}^{3} \text { ) }\end{array}$ \\
\hline Africa & & $2000 \mathrm{pcs}$ & 13.0 & 7.0 \\
\hline \multirow[t]{2}{*}{ Of which: } & RSA & 923 pcs & 3.5 & 1.9 \\
\hline & Egypt & 372 pcs & 7.1 & 4.0 \\
\hline America & & $21000 \mathrm{pcs}$ & 97.0 & 56.0 \\
\hline \multirow[t]{3}{*}{ Of which: } & USA & 16583 pcs & 60.4 & 41.0 \\
\hline & Mexico & 2289 pcs & 7.5 & 3.1 \\
\hline & Canada & $1265 \mathrm{pcs}$ & 6.6 & 5.6 \\
\hline Asia & & 8000 pcs & 130.0 & 62.0 \\
\hline \multirow[t]{2}{*}{ Of which: } & China & 3272 pcs & 38.0 & 26.6 \\
\hline & Japan & 2148 pcs & 16.9 & 11.6 \\
\hline Europe & & 47000 pcs & 52.0 & 37.0 \\
\hline \multirow[t]{7}{*}{ Of which: } & Germany & 9933 pcs & 5.3 & 5.2 \\
\hline & $\begin{array}{c}\text { United } \\
\text { Kingdom }\end{array}$ & $8035 \mathrm{pcs}$ & 4.1 & 4.0 \\
\hline & Russia & $7836 \mathrm{pcs}$ & 12.3 & n.a. \\
\hline & Poland & 4253 pcs & 2.3 & 1.4 \\
\hline & France & $3280 \mathrm{pcs}$ & 3.8 & 3.7 \\
\hline & $\ldots$ & & & \\
\hline & Hungary & 593 pcs & 0.2 & n.a. \\
\hline Australia & & $580 \mathrm{pcs}$ & 2.1 & 2.0 \\
\hline
\end{tabular}

Source: FAO, 2016. 
In the developed countries, the produced wastewater is primarily treated in large-scale wastewater treatment plants. The wastewater treatment activity is such an obligation for both the settlements and agricultural and industrial plants, in which besides the proper purification effect it is important to strive for effective operation and to minimize operating costs and/or maximize revenues. Besides the energetic opportunities, many macro elements can be separated during the treatment process.

These bigger plants generally operate based on the activated sludge process. This process was invented in England in the beginning of the $20^{\text {th }}$ century. It has since been adopted worldwide as a secondary biological treatment for domestic wastewaters and consists essentially of an aerobic treatment that oxidizes organic matter to $\mathrm{CO}_{2}, \mathrm{H}_{2} \mathrm{O}, \mathrm{NH}_{4}$, and new cell biomass. Air is provided by using diffused or mechanical aeration (BITTON, 2005). This type of wastewater treatment process is globally used for treating sewage and/or industrial wastewaters using aeration and a biological floc (sludge), which is composed of bacteria and protozoa.

A conventional activated sludge process includes the following:

Aeration tank, where aerobic oxidation of organic matter is carried out.

Sedimentation tank, which is used for the sedimentation of microbial flocs (sludge) produced during the oxidation phase in the aeration tank. A portion of the sludge in the clarifier is recycled back to the aeration basin and the remainder is wasted to maintain a proper $\mathrm{F} / \mathrm{M}$ (food to microorganisms ratio) (STERRITT and LESTER, 1988; BITTON, 2005).

Wastewater treatment plants are frequently ranked as the top individual energy consumers run by municipalities. Therefore, energy consumption for wastewater treatment is a matter of concern on a microeconomic scale and saving potentials need to be explored (WETT et al., 2007).

The wastewater treatment plants cannot be considered as only the place of the compulsory treating and purification activity but as like excellent raw material mines. An additional opportunity is to utilize the macroelements and the $\mathrm{CO}_{2}-$ content of flue-gas with algae and utilize the produced algae as fodder, bio-fuel or for other purposes (BAI, 2011).

The efficient operation of these plants is crucial nowadays. There are different opportunities connected to the energetics of this process. The most common option in large-scale treatment plants is the biogas production based on the produced sludge. Anaerobic digestion is the only energy-positive technology widely used in wastewater treatment (JENICEK et al., 2012).

\section{The biogas process}

The history of discovering biogas dates back to the 17th century, when Shirley discovered the marsh gas in 1677. In 1776, Volta found that it is a combustible material, and Dalton detected its methane-content in 1804. After that, the development of the method was rather fast: the first biogas plant was implemented in the Indian Mantunga in 1856, and the biogas was used for public lighting in Exeter in England (BAI, 1998).
Based on the data of EUROBSERV'ER (2014), the EU produced almost 13,380 ktoe of biogas in 2013 with more than 14,000 operating anaerobic digesters. Germany is responsible for the $50 \%$ of the produced biogas, while Hungary has a midfield position regarding the amount of produced biogas. There are three different category concerning the origin of the produced biogas. These categories, and the proportion of them are shown below:

Landfill gas: $22 \%$

Sewage sludge gas (urban and industrial): $9 \%$

Others biogas (decentralised agricultural plant, municipal solid waste methanisation plant, centralised co-digestion plant): $69 \%$.

Biogas plants in Hungary were primarily implemented with the purpose of waste management and most of them produce electricity and heat (in cogeneration) from the produced biogas. This fact can be justified by the direct heat utilization: it is almost impossible to use biogas only for thermal energy production in larger sizes during the summer period (BAI, 2015).

\section{Biogas and wastewater treatment}

The biogas technology was firstly used in wastewater treatment plants in Germany in 1920. Nowadays, there are 32 biogas plants which operate based on wastewater treatment plants in Hungary, typically in middle-sized and larger settlements. The overall capacity of the biogas plants is more than $19.5 \mathrm{MWp}$, and most of the biogas plants operate in cogeneration (both electricity and heat production) (HUNGARIAN BIOGAS ASSOCIATION, 2017; PAN-LNG PROJECT, 2016).

\section{Energy opportunities: minimizing operation costs and/ or maximizing revenues}

Two important options are the wastewater-based biomethane production and the energy self-sufficiency of certain plants. In the former case, it is possible to utilize the wastewater-based biomethane as fuel (and even to operate own vehicle fleet), while the latter one gives the opportunity for the internal usage of produced electricity and waste heat, which can also result in significant cost-savings.

Biomethane production is primarily gaining in popularity with the countries of the European Union, because it enables them to reduce their reliance on natural gas imports (EUROBSERV'ER, 2014). In the EU, there are three hundred plants in 15 countries recently, where biomethane is produced from biogas. Fuel production from the wastewater-based biogas was firstly implemented in Finland, where one hundred biomethane-fueled vans and buses operated in 1941.

In Hungary, there are two plants, which produce biomethane. The first one is in Kaposvár, where the produced biomethane is feeded into the natural gas pipeline. The plant started to operate in September 2015, which investment cost was one billion HUF. The annual biomethane production is five billion $\mathrm{m}^{3}$. The main raw materials are waste sugar 
beet and sewage sludge. The second city is Zalaegerszeg, where the produced biomethane is used as fuel by the city's public transport vehicle fleet (twelve vans and three buses). In Zalaegerszeg, the operation started in September 2011, and the investment cost was 140 million HUF (120 million HUF for the biogas clarification system and 20 million HUF for the implementation of the filling station). The daily biomethane production is $3,600 \mathrm{~m} 3$. The main raw material of the plant is sewage sludge and wastes from meat industry. The production cost of the biomethane is $0.52 \mathrm{EUR} / \mathrm{m} 3$ (0.8 1 gasoline $/ \mathrm{m} 3$ biomethane) (PAN-LNG PROJECT, 2016), which is less than half of the recent price of the gasoline in 2017.

Minimization of energy consumption and thus the operating costs has become nowadays a major goal for wastewater treatment plant (WWTP) operators. Many researchers started to investigate various aspects of the possibilities of energy selfsufficiency in WWTPs (CHUDOBA et al., 2011; SVARDAL and KROISS, 2011; BALMÉR and HELLSTRÖM, 2012; JENICEK et al., 2012). According to SCHWARZENBECK et al. (2008) and BALMÉR and HELLSTRÖM (2012), the easiest way to increase biogas production and improve the WWTP's energy balance is to supply an external organic substrate. However, NOWAK et al. (2011) reported examples in which WWTP's self-sufficiency was achieved without the need for such organic substrates.

\section{MATERIALS AND METHODS}

There are various energy opportunities regarding the large-scale wastewater treatment activity. Concerning the topics of biomethane utilization and energy self-sufficiency, this article is written mostly for review purpose. In the case of biogas production and self-sufficiency, a special solution could be adoptable into the traditional wastewater treatment system, which is the algal post-treatment. The designing of carbon-dioxide passivation in algae ponds can be based on different aspects. The amount of $\mathrm{CO}_{2}$ or the required purification capacity (amount of residual micro and macro elements in the wastewater) can fundamentally determine the sizing issues. For the purpose of proper photosynthetic activity, separation of the substrate and transparent water is needed (with a maximum water depth of 0.5-0.6 m).

The basic data provided by the Debrecen WWTP are the following:

- amount of produced biogas: 2,360 thousand Nm3/ year (3-years average)

- composition of biogas: $58-62 \%$ methane $\left(\mathrm{CH}_{4}\right), 27$ $31 \%$ carbon dioxide $\left(\mathrm{CO}_{2}\right), 1 \%$ other gases

- heating value of biogas: $23.2 \mathrm{MJ} / \mathrm{Nm}^{3}$

- electric capacity: $1.79 \mathrm{MW}$

- amount of produced electricity: 6,275 MWh/year (3year average)

(Source: DEBRECEN WATERWORKS, 2017)

Due to the lack of exact data regarding the characteristics of $\mathrm{CO}_{2}$-emission factor of WWTPs, the determination of this factor was prepared based on the amounts of national
$\mathrm{CO}_{2}$-emission and electricity production data concerning the cogeneration power plants (Figure 1-2.).

Figure 1: CO2-emission and electricity production of Hungarian power plants

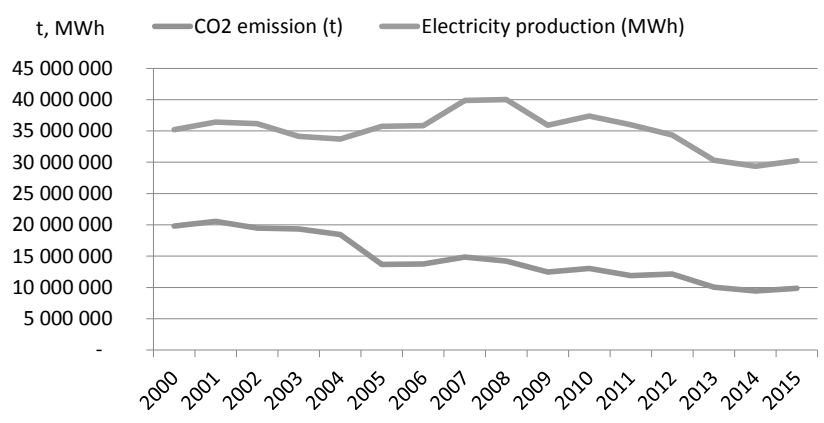

Source: Author's construction based on data of MAVIR Hungarian Independent Transmission Operator Company

(Data of the Hungarian Electricity System, 2015)

Figure 2: CO2-emission factor of Hungarian power plants (2000-2015)

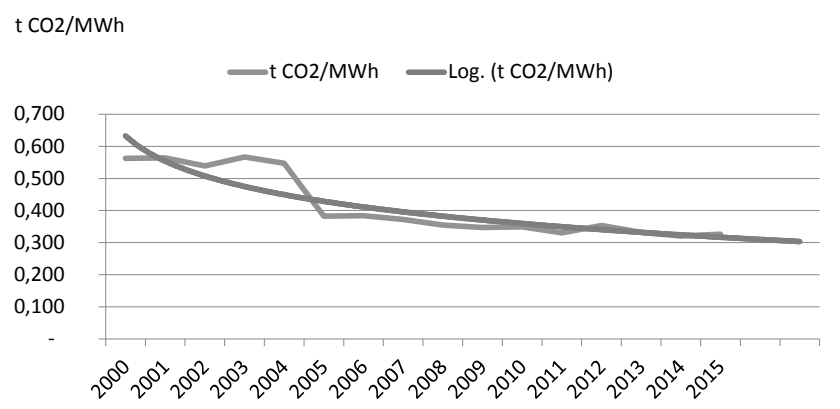

Source: Author's own calculations and construction based on data of MAVIR Hungarian Independent Transmission Operator Company (Data of the Hungarian Electricity System, 2015)

In order to determine the value of $\mathrm{CO}_{2}$-emission factor $\left(0,32 \mathrm{t} \mathrm{CO}_{2} / \mathrm{MWh}\right)$ in 2017 , a logarithmic trend has been fitted to the curve based on the data of the previous years.

Value of $\mathrm{CO}_{2}$-kvote was estimated based on the actual price of $\mathrm{CO}_{2}: 6,94 \mathrm{EUR} / \mathrm{tCO}{ }_{2}$ (BLOOMBERG, 2017).

\section{RESULTS AND DISCUSSION}

\section{The minimization of the WWTP's energy consumption}

According to the study of JENICEK et al. (2013), the energy content of sewage is several times higher than the energy required for its efficient treatment. Their results show that, due to the anaerobic digestion of the sludge produced during wastewater treatment, the goal of energy self-sufficient sewage wastewater treatment plants is a realistic opportunity. With the optimizations, biogas production increased significantly to $12.5 \mathrm{~m}^{3}$ per population equivalent per year. In turn, this led to an equally significant increase in specific energy production from approximately 15 to 23.5 
kWh per population equivalent per year. WETT et al. (2007) presented experiences from Central Europe that point towards large energy saving potentials of typically 30-50\%, which are just gradually being exploited nowadays. The large-scale municipal WWTP in Strauss (Austria) has already reached a positive energy balance without any relevant co-substrates.

Figure 3. shows the characteristics of energy management of Debrecen WWTP.

Figure 3: Electricity management of the Debrecen WWTP (May 2015 - July 2017)

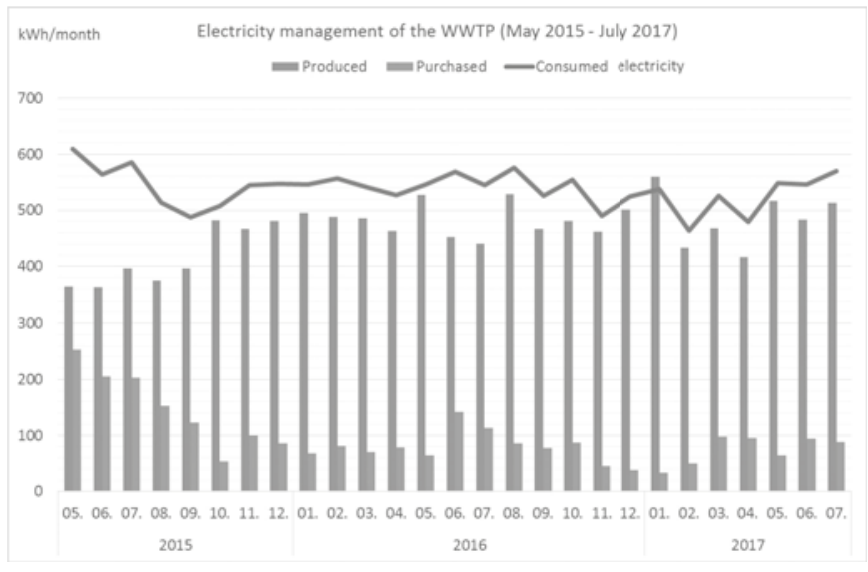

Source: Author's construction based on Debrecen Waterworks Plc., 2017

The improvement in biogas production is primarily due to the increased pre-sedimentation step with Fe and $\mathrm{C}$ addition, which results in higher energy production. The increasing share of the produced electricity results in higher level of energy self-sufficiency, due to increased biogas production. This level significantly changed from approx. 65\% (2015) to 92-95\% (2017). Besides the increased electricity production, higher amount of heat production was another advantageous effect, which could serve the energy self-sufficiency as well in the digesters. For about eight months, the WWTP provides waste heat to one of the city's housing estates.

The amount of consumed biogas and natural gas shows that the changes in technology have led to an increase in monthly biogas production. The decreasing amount of purchased natural gas is due to the fact that the surplus biogas has provided sufficient energy source to trigger the reduction in natural gas consumption and thus reduce the operating cost of the WWTP. In addition, the plant has been able to produce higher amount of electricity based on the biogas production, as it is shown in Table 1. All of these result in significant savings in energy costs (TRUZSI et al., 2017).

In the case of large-scale wastewater treatment, it is important to pay attention to the different by-products such as the large quantities of sewage sludge or the $\mathrm{CO}_{2}$-content of the flue gas generated during the combustion of the produced biogas. The former one can be utilized primarily as fertilizer or as a valuable component of compost, while the latter one offers an excellent opportunity for use in algae ponds. In this case, the micro and macro elements of purified wastewater can be further utilized. Based on the study of WANG et al. (2010) and LI et al. (2011), the following reduction effect can be achieved during a 14-21 days-long algae treatment: nitrogen content (82-89\%), phosphorus content (40-81\%), chemical oxygen demand (39-91\%).

Algae can also play an important role in the containment of pollutants. In many cases, the lack of carbon dioxide occurs as an important limiting factor, because the natural $\mathrm{CO}_{2}$ concentration is only $0.039 \mathrm{v} / \mathrm{v} \%(390 \mathrm{ml} / \mathrm{l})$ in the air and only $0.7 \mathrm{ml}(1.4 \mathrm{~g} / \mathrm{l})$ diffuses into the water in equilibrium. Therefore, $\mathrm{CO}_{2}$ gas emitted by the biogas plant can be used for replacing it. On the other hand, algae can utilize the micro and macro elements remaining in the outgoing wastewater. The initial data concerning size (energy capacity) and capacity utilization are based on the characteristics of the Debrecen WWTP, while the $\mathrm{CO}_{2}$-fixation effect and potential yield of algae (regarding Chlorella Vulgaris specie) are based on the study of BAI et al. (2012, 2017).

According to the calculations based on the data of Debrecen WWTP, the operation hours are 3505 annually, which corresponds to the national average. In my calculations, I have determined the potential $\mathrm{CO}_{2}$-emission capacity, $\mathrm{CO}_{2}$ fixation and $\mathrm{CO}_{2}$-emission concerning algae post treatment and thus algae production (Table 2.)

Table 2: Theoretical potential of $\mathrm{CO}_{2}$-fixation by algae in the Debrecen WWTP

\begin{tabular}{|l|l|l|}
\hline Title & Measure & Value \\
\hline $\mathrm{CO}_{2}$-emission & $\mathrm{t} \mathrm{CO}_{2}$ & 2008 \\
\hline $\mathrm{CO}_{2}$-fixation by algae & $\mathrm{t} \mathrm{CO}_{2}$ & 527 \\
\hline $\mathrm{CO}_{2}$-emission in production & $\mathrm{t} \mathrm{CO}_{2}$ & 79 \\
\hline $\mathrm{CO}_{2}$-kvote & $\mathrm{EUR} / \mathrm{t}$ & 6.94 \\
\hline Value of saved $\mathrm{CO}_{2}$ & $\mathrm{EUR}$ & 3,109 \\
\hline Amount of algae & $\mathrm{t}$ & 2,394 \\
\hline Algae yield & $\mathrm{t} / \mathrm{ha}$ & 248 \\
\hline Surface of algae ponds & hectare & 10 \\
\hline
\end{tabular}

Source: own construction

Table 2. shows that $\mathrm{CO} 2$-fixation capacity of algae is approx. 527 thousand tons, while the value of $\mathrm{CO} 2$ saved by the algae breeding is 3,109 EUR. According to my calculations, the estimated amount of produced algae is 2,394 tons and the necessary surface of algae ponds is 10 hectares. For this reason, a 20-22 hectares territory near the Debrecen WWTP (which should be recultivated in the near future) could be a suitable location. The produced algae biomass could be utilized for bioenergy production or for other purposes as well. 


\section{CONCLUSIONS}

In the future, wastewater treatment facilities will increasingly claim their role as resource recovery plants, instead of nutrient removal systems. This recovery will be realized not only in terms of water and nutrients but also of energy. I would like to highlight the importance and possibilities of waste and by-product utilization as raw material, where rational, prudent and sustainable utilization is crucial, based on detailed economic calculations and feasibility studies. All of the above mentioned technological solutions could have many advantages, although the main problem regarding these technical solutions is the high investment cost. Biomethane production using cost-efficient biogas-cleaning technologies could serve petrol independence, which could be an important issue in the future. Emission reduction in the downtowns could be a positive effect as well, while the available cost saving of the biomethane production is more than $40 \%$ + VAT compared to the fossil fuels. Nevertheless, the biomethane production and utilization are in the early stage of development. It has little significance in Hungary nowadays, and has concurrences like electric and LPG powered transport. One of the main problems of the biogas technology is the utilization of waste heat during the summer period, which can significantly determine the economic characteristics of the given plant. As opportunities for the waste heat of wastewaterbased biogas plants, utilization in district heating system, agricultural activities (dryer, greenhouse or as technological heat) should be also mentioned. Another by-product is the generated $\mathrm{CO} 2$ from the flue gas. Utilizing through successful algae breeding, the expected value of the produced algae could exceed the arising costs. The estimated amount of produced algae is 2,394 tons and the necessary surface of algae ponds is 10 hectare, while the value of saved $\mathrm{CO} 2$ is approximately 3,109 EUR. Furthermore, better quality of outgoing water is ensured during this process.

\section{ACKNOWLEDGEMENTS}

I would like to express my gratitude to the Debrecen Waterworks for the assistance regarding plant operation data.

\section{REFERENCES}

Bai A. (1998): A mezőgazdasági és élelmiszeripari melléktermékek energetikai hasznosításának gazdasági összefüggései. Disszertáció. Debreceni Agrártudományi Egyetem, Debrecen. $168 \mathrm{p}$.

Bai A. (2011): Újabb generációs bio-üzemanyagok perspektívái, Magyar Tudomány 2011, 172(7): 861-871.

Bai A., Stündl L., Bársony P., Fehér M., Jobbágy P., Herpergel Z., Vaszkó G. (2012): Algae production on pig sludge, Agronomy for Sustainable Development 2012, 32(3): 611-618. DOI: 10.1007/s13593-011-0077-2

Bai A. (2015): Helyi közlekedés és hulladékgazdálkodás, Magyar Energetika, 2015, 22(1): 21-25.
Bai A., Popp J., Petô K., Szôke I., Harangi-Rákos M., Gabnai Z. (2017): The Significance of Forests and Algae in CO2 Balance: A Hungarian Case Study, Sustainability 2017, 9: 857. DOI: $10.3390 / \mathrm{su} 9050857$

Balmér P., Hellström D. (2012): Performance indicators for wastewater treatment plants, Water Science and Technology, 2012, 65(7): 1304-1310. DOI: 10.2166/wst.2012.014

Bitton G. (2005): Activated sludge process, Wastewater Microbiology, 3rd ed. John Wiley \& Sons, Inc. 2005 ISBN: 9780471650713. DOI: 10.1002/0471717967

Bloomberg (2017): Energy, Emissions. Data accessed: 20.05.2017. Available online: https://www.bloomberg.com/energy.

Chudoba P., Sardet C., Palko G., Guibelin E. (2011): Main factors influencing anaerobic digestion of sludge and energy efficiency at several large WWTP in central Europe, Journal of Residuals Science \& Technology 2011, 8(2): 89-96.

EurObserv'ER (2014): Biogas Barometer. Data accessed: 10.05.2017. Available online: http://www.energies-renouvelables.org/observ-er/stat_baro/observ/baro224_Biogas_en.pdf.

FAO (2016): Number of municipal wastewater treatment facilities. Data accessed: 18.09.2016. Available online:

http://www.fao.org/nr/water/aquastat/data/query/results.htm l? regionQuery $=$ true \&yearGrouping $=$ SURVEY\&yearRange. fromYear $=1960 \&$ yearRange toYear $=2015 \&$ varGrpIds $=4515$ $\&$ regIds $=9805,9806,9807,9808,9809 \&$ includeRegions $=$ true $\&$ showValueYears $=$ true $\&$ categoryIds $=-1 \&$ XAxis $=$ YEAR $\& s$ howSymbols $=$ true $\&$ showUnits $=$ true $\&$ hideEmptyRowsColou $\mathrm{mns}=$ true\&_hideEmptyRowsColoumns $=$ on\&lang $=$ en\&que ry_type $=$ glossary.

FAO (2016): Treated municipal wastewater (10^9 m3/ year). Data accessed: 18.09.2016. Available online: http:// www.fao.org/nr/water/aquastat/data/query/results.html?re gionQuery $=$ true \& yearGrouping $=$ SURVEY\&yearRange. fromYear $=1960 \&$ yearRange. toYear $=2015 \&$ varGrpIds $=4270$ $\&$ regIds $=9805,9806,9807,9808,9809 \&$ includeRegions $=$ true $\&$ showValueYears $=$ true $\&$ categoryIds $=-1 \&$ XAxis $=$ YEAR $\& s$ howSymbols $=$ true $\&$ showUnits $=$ true $\&$ hideEmptyRowsColou $\mathrm{mns}=$ true \&_hideEmptyRowsColoumns $=$ on\&lang $=$ en $\&$ que ry_type $=$ glossary.

Hungarian Biogas Association (2017). Data accessed: 18.05.2017. Available online: http://www.biogas.hu/2/frameset

Jenicek P., Bartacek J., Kutil J., Zabranska J., Dohanyos M. (2012): Potentials and limits of anaerobic digestion of sewage sludge: energy self-sufficient municipal wastewater treatment plant?, Water science and technology 2012, 66(6): 1277-1281. DOI: $10.2166 /$ wst.2012.317

Jenicek P., Kutil J., Benes O., Todt V., Zabranska J., Dohanyos M. (2013): Energy self-sufficient sewage wastewater treatment plants: is optimized anaerobic sludge digestion the key?, Water Science and Technology 2013, 68(8): 1739-1744.

Li Y., Chen Y. F., Chen P., Min M., Zhou W., Martinez B., Zhu J., Ruan R. (2011): Characterization of a microalga Chlorella sp. well adapted to highly concentrated municipal wastewater for nutrient removal and biodiesel production, Bioresource Technology 2011, 102(8): 5138-5144. DOI: 10.1016/j. biortech.2011.01.091 
MAVIR Hungarian Independent Transmission Operator Company (2015): Data of the Hungarian Electricity System. Available online: Data accessed: 16.05.2017. http://mavir.hu/documents/10258/154394509/VER-statisztika+2015+-+Final 1. pdf/f9111e9f-b7cf-44fc-a0b6-bb391f3e8144

Nowak O., Keil S., Fimml C. (2011): Examples of energy selfsufficient municipal nutrient removal plants. Water Science and Technology 2011, 64(1): 1-6. DOI: 10.2166/wst.2011.625

PAN-LNG Project (2016): PAN-LNG Project Study 1.7. Data accessed: 16.01.2017. Available online: http://www.panlng.eu/ wp-content/uploads/2016/06/1_7_PAN-LNG_biogaz.pdf.

Schwarzenbeck N., Pfeiffer W., Bomball E. (2008): Can a wastewater treatment plant be a powerplant? A case study, Water science and technology 2008, 57(10): 1555-1561. DOI: 10.2166/wst.2008.215

Sterritt R. M., Lester J. N. (1988): Microbiology for environmental and public health engineers. E. \& FN Spon. Agris 1988, FAO

Svardal K., Krois H. (2011): Energy requirements for waste water treatment, Water Science and Technology 2011, 64(6): 1355-1361. DOI: 10.2166/wst.2011.221

Truzsi A., Bodnár I., Fülöp Z. (2017): A debreceni szennyvíztisztító telep biogáz termelő fermentációs folyamatainak nyomon követése kémiai módszerekkel. Monitoring of Debrecen WWTP biogas fermentation processes by chemical methods, International Journal of Engineering and Management Sciences 2017, 2(1): 79-83. DOI: 10.21791/IJEMS.2017.1.15.

Wang L., Li Y., Chen P., Min M., Chen Y., Zhu J., Ruan R. R. (2010): Anaerobic digested dairy manure as a nutrient supplement for cultivation of oil-rich green microalgae Chlorella sp, Bioresource Technology 2010, 101(8): 2623-2628. DOI: 10.1016/j.biortech.2009.10.062

Wett B., Buchauer K., Fimml C. (2007): Energy self-sufficiency as a feasible concept for wastewater treatment systems. In: IWA Leading Edge Technology Conference, Singa-pore: Asian Water. 2007: 21-24. 